\title{
Vitamin B2 Measurement
}

National Cancer Institute

\section{Source}

National Cancer Institute. Vitamin B2 Measurement. NCI Thesaurus. Code C74898.

The determination of the amount of Vitamin B2 present in a sample. 